\title{
Cultural Identity of Adolescents in Serbia in the Digital Environment ${ }^{1}$
}

316.723-053.6"20"

316.7:004.7

DOI 10.18485/fdu dhkum.2021.ch6

\section{Introduction}

Psychologically, a human being develops throughout life. In certain periods of life, the development of heightened intensity is more important for the creation or reorganization of a psychic being - its basic traits and basic psychic structure (Ćurčić, 2004). The last such period in a person's life is adolescence, during which children are transformed into physically, psychologically, emotionally, cognitively, and socially adults. Most developmental psychology schools agree that adolescence spans the age of 12 to 25 .

Adolescence is a process that leads to a change in many aspects of the adolescent's inner world, as well as the adolescent's correlation with the environment. In order to achieve autonomy and form one's own identity, the adolescent begins the process of psychological separation from the parent. She seeks emotional support and a sense of belonging among peers and partners (Vranješević, 2004). Identification, which is one of the key needs and tasks in adolescence, involves the processes of separation, differentiation,

1 Some segments of this paper are contained in a doctoral dissertation entitled: "Media Literacy in Secondary Education: An Incentive for Critical Thinking of Adolescents in Serbia at the Beginning of the 21st Century" (Faculty of Dramatic Arts, University of Arts, Belgrade). 
subjectification, and new identifications. Increasing parental independence and final separation, the adolescent will come to after desidealizing his parents' infantile performances. From this process, there will be a need for new identifications with objects outside the family, most often peers or celebrities from the music world ${ }^{2}$, to a lesser extent sports.

The cultural identity of a social group is seen in the science of culture as a form of collective consciousness, feelings, and behavior, which show belonging to a community (Leslie, 1970; Avramović, 2006). The complexity of the meaning of the term "cultural identity of adolescents" includes all the symbols and meanings that determine the belonging of that social group to the wider community and that distinguish them, or make them similar, from other groups in that community. The structural elements of each cultural identity are objective indicators and their subjective experience (Avramović, 2006: 22).

Digital culture is a phenomenon that is historically conditioned, primarily in response to the calculation and encryption of messages in World War II, and later modern capitalism, information technology innovation and technological science discourses on information and systems, avant-garde artistic practices and countercultural utopianism, critical theory and philosophy (Gere, 2008). Considering the position that adolescents occupy in digital culture is interesting and scientifically provocative due to the strong interaction between factors - on the one hand, young people, which significantly influence the formation of new cultural values, and on the other hand information and communication technologies and media that largely determine cultural a cross-section of the current

2 The type of music the adolescent listens to refers to his inner state and the psychodynamics of the adolescent development process. The philosophy of musical direction, or genre, reveals what the adolescent is looking for a solution and meaning for - punk suggests punctuality, inner distraction and aggression, alternatives to depressing disinvestment of the object world due to lack of narcissistic expectations, local pop music city records to narcissistic culture, the need to leave an impression of untouchability, beauty, power, as well as putting the outside, object world, in the function of one's own mirror (Ćurčić, 2004). 
epoch. The peculiarities of one social group will influence the direction of the development of culture and its values more than in the earlier epochs of evolution. Are adolescents less courageous today, more pragmatic, and passive than they were fifty years ago? To what extent is the cultural identity of adolescents at the beginning of the 21st century determined by the mediacentric environment and rapid technological advancement in the digital age? Through theoretical consideration and empirical research on adolescents, we will endeavor to provide answers to the questions raised, pointing to the key points of determining the cultural identity of adolescents in Serbia at the beginning of the 21st century.

The essential problem in understanding the cultural identity of adolescents is in the way of interpreting the patterns of actualization of adolescents over time - their habits, features of the language they use (sociolect), values they believe in and nurture, which are substitutes for the myths of their distant ancestors. Changes in the media, conditioned by new information and communication technologies, have also changed the way of thinking about oneself and the current social reality. The aim of this theoretical consideration and analysis of the results of the conducted empirical research is to determine the attitude of adolescents towards the media, to single out the media that young people use the most today, to determine the way they actualize themselves in the environment through the media. Given the fact that their attitude towards the media can be viewed as the collective consciousness of a social group, as a pattern-based behavior, we conclude that adolescents' attitudes toward the media, how they use them, and the channels through which they communicate are a relevant indicator of their cultural identity.

\section{Adolescents in Serbia at the beginning of the 21st century}

Expectations from adolescents to fit into established roles imposed by adults, appropriate to the cultural context of their 
parents 'and teachers' growing up, interpreting adolescents 'pursuit of meaning and autonomy as rebelliousness ${ }^{3}$, destructing and disorienting adolescents, lead to widening the gap between adolescents' inner and outer realities. As a result, more and more psychology schools are seeing the only correct direction for thinking about adolescents by shifting to the adolescents' point of view and appreciating their approach to changing reality. This line of thinking leads us to wonder how much today's adolescents are striving to change. In the mediacentric world, technologies are both social and cultural tools. With their help, today's adolescents introduce themselves and establish new communication rituals.

At the beginning of the 21st century, the perception of one's own being and reality for adolescents was, more than before, indirect knowledge, established through the mediation of media constructs. Dealing with questions that encourage and reveal psychological growth: Who Am I? What is the world around me? What is its meaning?, leads to responses significantly conditioned by the perception of the continuous series of simulacrums that make up adolescents' everyday lives. In a period such as adolescence, the call for insight into one's own being and its correlation with the world has greater significance and special significance, since all three questions are asked for the first time in life. Curčić notes that the basic task of adolescents in such a contradictory and tumultuous period is often to survive only, while finding meaning is possible only later, in post-adolescence - "until then there is

3 At the root of the rebel phenomenon is the archetype of the bowman, the one who brings light and through it takes the people out of the darkness (the underworld). He boldly fights authority. From the same archetype will develop the Babylonian god Zuu, who fell to Earth in the form of a fiery flying snake, Egyptian serpent god Setu, the father of lightning, who also fell to Earth, Prometheus, a titan of Greek mythology, who rebelled against the gods and stole fire them to give it to the people, Lucifer, a biblical fallen angel, a renegade from God, etc. Carl G. Jung interprets man's notions of the good works of renegade gods as a symbol of the relativity of morality. Describing the nature of butler as a double, Jung points out that "paradox is one of the fundamental qualities of the unconscious and its contents" (Jung, 1987: 72-73). 
only wandering and a chaotic and highly variable illusion, at best just a fickle idea of meaning their own existence and life" (Ćurčić, 2004: 11).

Adolescents today are born in the late 90s and early 2000s. Growing up in Serbia from the late 90s to the present implies certain specificities that have determined the social context and influenced the peculiarities of the development of many factors - family, school, environment, adopted value system, relation to the future, personal and collective identity, etc. NATO bombing of Serbia in 1999, years of isolation, decades of political and economic crisis, continuous migration of the population, changing the socio-political borders of the country and its name, the departure of socialists and the arrival of Democrats in power, unmet citizens' expectations, the assassination of the Prime Minister, resignation and loss of faith and will for change, denial of citizens' freedom and rights, restoration and strengthening of totalitarianism, media crises, several incomplete primary education reforms, and secondary education reform initiated, as well as all other specifics of Serbian social reality, created a unique social context of the heritage and environment of today's adolescents.

With adolescents in other countries of Western civilization, they are joined by common age characteristics and commonplaces of a current cultural and historical moment - consumer society, globalization and mediation, information overflow, which led to diminished or, Baudrillard, lost will to act (Bodrijar/Baudrillard, 1991). They are locally determined by their dissatisfaction with the existing order, but also by the lack of hope that anything in society will change, confusion, anxiety, and passivity, with many desiring to continue living abroad after high school or college ${ }^{4}$. This context is increasingly complemented by the diminished

4 The insight was derived as the conclusion of the author from teaching practice during the course 2017/2018. and 2018/2019. with adolescents in the Fifth Belgrade Grammar School, through teaching literature of realism and existentialism, where a comparative approach to the social contrast of the literary work was applied to the current social reality. The above conclusion was reached by the open-ended interview method and by comparative analysis. 
functionality of the parental role, that is, the overall dysfunction of the family ${ }^{5}$.

High school students are "the age group most affected by the educational and social situation" (Pavlović-Babić et al., 2001: 206). Societies that are in turmoil, such as ours from the late 20th century to the present, are far from the desirable environment for adolescent inner reality. Fearing the effects of the inappropriate social environment for adolescents in Serbia, writer and critic Teofil Pančić paints a powerful message: "Do not be a direct replicant of all that junk you grew up with!" (Pančić in Vranješević, 2004: 168).

The impact of adverse social context on adolescents in Serbia can be significantly diminished by encouraging critical thinking, primarily about media content, that is, by developing media literacy.

In the digital culture of the early 21st century, selfie photography is an archive of the personal perception of one's own being, the explicit and implicit self-representation of the adolescent, a media construct that meets the humble need for the aesthetic. For adolescents, selfie is a mimetic reflection of the unconscious pursuit of self. The selfie photos of today's adolescents show the play that others want to adopt about them. The results of the published study on adolescents in Serbia indicate the pronounced presence of narcissistic culture and technologies in the everyday life of adolescents ${ }^{6}$.

5 The diminished functionality of parents in this context is reflected in the poorly and poorly spent time with adolescents, the material compensation for lack of attention and conversation, the replacement of roles in the parent-child relationship, the devaluation of parents by adolescents, leading to increasing vulnerability and also adolescent violence, as well as strengthening the need for power, above all economic and social (Vranješević, 2004).

6 The study was conducted on a sample of 60 adolescents aged 17 and 18, students of Fifth Belgrade High School, in 2016. The aim of the study was to determine the presence of the aesthetic being (homo aestheticus) of today's adolescents. The results showed that the understanding of aesthetics in the examined adolescents is present, but changed in comparison with earlier epochs. Today's young homo aestheticus creates his own identity against the backdrop of the digital platform and views himself as an aesthetic construct. A significant number of young people 
The social environment offers adolescents the objects and patterns of behavior, value systems, and moral norms, that is, patterns of relating to the world. Social patterns and objects adapt to the inner and individualize, becoming an integral part of the adolescent's inner reality. At the same time, the individualities of each individual's inner world are projected into social reality and adjusted to the external ("socializing"), so it is difficult to say who is more affected by it: adolescents to society or adolescent society (Tadić, 2004: 164). Paradoxically to the development of information technologies, the processes of "socialization" give way to processes of individualization, which in the more educated part of the adolescent social group reach the level of ultra-individualism and narcissism (Gauchet, 2002).

\section{The impact of media on adolescents}

The power of the media lies in the fact that the media are creators of social and individual reality. Media can give importance to ordinary people and ordinary events, and influence the creation of social history. The world of digital media is the world of today's adolescents. Therefore, it is important to view simulacrums from their environment, media content, and messages whose dialectic orbits between existing traditional knowledge and the growing capabilities of new media and information technology as a valuable vault of stimulants to encourage their critical thinking. At the same time, by looking at the media positioning of their social group at a particular historical moment, adolescents can recognize the expectations that the community has set for them. Learning about media literacy will provide them with critical autonomy and enable them to master the skills needed for lifelong learning in an ever-changing world.

Media impact research involves experiments and surveys that generate quantitative data to find out how exposure to media

satisfy the need for beautiful viewing of others' selfies, as well as the production and viewing of their own, which represents an altered object reality, qualified among adolescents as "aesthetic" (Kecman, 2017). 
content influences thinking and action (Gunter, 2008; Sundar, 2009). Why is research into the impact of media on adolescents important? Observing the youth and exploring the impact of the media on them enables one to see the direction of social movements in the future.

Exploring the phenomenon of learning from the media and taking a critical stance on violence in media content, Gunter points out the complexity of the process itself:

There are several stages in the cognitive processing of media violence. Viewers need to be aware of its unfolding, understand its purpose in the broader context of the narrative, evaluate its role, purpose, and outcomes for participants, and absorb its details into one's own knowledge of society so that new behavioral events can be compared with other experiences as well as to be modified in the process. (Gunter, 2008: 1089)

In considering the impact of the media on the individual, Bryant and Oliver conclude that the media do not exert a direct, immediate influence. Second, the impact that media will exert on an individual depends on his or her motives for using media content (Bryant \& Oliver, 2009). Ulla Carlsson points to two currents in public attitudes toward the impact of media on youth - one advocating the diminishing power and expansion of the media industry and the other focused on media relations research (Carlsson et al., 2008).

Considering the pluralism of attitudes regarding the impact of media on youth, Andy Ruddock concludes that the way young people and the media are understood and studied influences the formation of researchers' attitudes. He believes that media researchers to some extent create the subject of their own analysis and that "it makes no sense for you to engage in discussion of youth media without considering and studying the subject as a cultural activity in itself " (Ruddock, 2013: 19). How the connection between the media and the youth is described and established influences the image that young people build about themselves in society, as well as the historical moment they are a part of. 
To determine the political impact of media on adolescents, it is important to start with the way adolescents are presented in the media. This picture reveals the intentions of the establishment, the attitude towards the mutual relations of social groups within the community, but also the hidden fears, the attitude about the perspective and importance of young people for the development of society as a whole. At the same time, studies on youth subcultures point to the fact that young people in the West in the early 21st century made significant use of media resources to communicate their political ideas and connect with political like-minded people (Ruddock, 2013: 11).

Adolescents' presence in media content can be most noticeable in advertising and populist discourse during political campaigns. Media content in which adolescents have potentially inhibiting messages relate to alcoholism, drug addiction, violence, nutrition, materialistic values of neoliberal consumer society, stereotypical representation of male and female bodies, racial, class, gender, and sexual identity.

Parents' concern about the inappropriate media content that adolescents come in contact with daily is an expression of adult anxiety caused by their inability to control children's access to the media (Denby, 1996, according to Hobbs, 1998). The controversy over the harmful impact of the media on young people has most often stemmed from the rise in cases of unacceptable adolescent behavior.

Anderson defines media that may adversely affect adolescents as "problem areas", identifying the following risk points of influence: alcoholism, drug addiction, violence, nutrition, materialistic perception, reporting bias, and stereotypical representation of the male and female body. racial, class, gender, and sexual identity (Anderson, 1983).

In the United States, adolescents' exposure to the media is viewed as a "risk factor" and media literacy in education as a "protective factor" (Hobbs, 1998). Renee Hobbs points to the results of a 1997 study by Austin and Johnson in the US, which shows that media literacy education can influence adolescents' behavior 
in their decision to drink. On the other hand, a significant number of media theorists and teachers in the UK believe that media literacy can protect adolescents from the negative impact of media is superficial and based on poorly placed social research (Halloran and Jones, 1992).

In their view, axiom-based teaching methods that media literacy protects adolescents from media influence are ineffective in everyday life.

Hobbs also believes that in media education, students' tasks are dysfunctional if media literacy skills are at odds with media culture. Many teachers with whom she collaborated argued that students do not respond to the idea that they are helpless victims of media influence, who must be rescued from media manipulation (Hobbs, 1998). Buckingham stated several years earlier, pointing out that focusing on the negative impacts of the mass media neglects the emotional engagement adolescents establish with the media. Instead of cynicism and superiority, Buckingham proposes well-conceived research and analysis, the results of which will provide adequate tools for educating children and adolescents about the media (Buckingham, 1993).

Media influence can only be understood in the context of the cultural setting and the historical moment in which it occurs. Therefore, we will look at the determination of media influence on adolescents in Serbia, as well as their media habits, in this vein, relying on the results of empirical research that we will present in the next section.

\section{Media used by adolescents}

According to a media message, today's adolescents relate without distance, integrating it as part of themselves, which is why they are popularly referred to as "media integrators", "generation Z", and "millennials". According to the genealogical link to the new

7 This term means born from 1995 to the present. 
media, they are also "digital natives" - the internet is the entity of their existence. Language follows the pulse of culture, and the emerging vocabulary indicates the need for society to name pervasive phenomena whose presence has become a social constant.

Over the last two decades, research on the attitude of young people to the media has been conducted frequently in the last two decades. The results of a study in Australia show that adolescents spend a large number of hours with the media every day - about 40 hours a week (Nettlefold, Williams, 2018) which means more than five hours a day. Approximately the same results are shown by research conducted in the United Kingdom (Buckingham, 2003) and the United States (Thoman, 2003).

Empirical studies in Serbia show no significant difference from the rest of the world. An empirical study conducted during 2018 at the Fifth Belgrade Gymnasium aimed at identifying adolescents 'media habits has provided us with valuable insight into the place, importance and ways of consuming media in adolescents' lives in Serbia. Below, we will highlight the research findings, analyze them through three structural sections of the questionnaire: adolescent media, adolescent media perception channels, and adolescent social media, and draw conclusions ${ }^{9}$.

8 The term "digital natives" is first mentioned in the work "Digital Natives, Digital Immigrants" by writer and software designer Marc Prensky. Contrary to this term, Prenski uses the term "digital immigrants" to mean users of new media who, in addition to the primary traditional modes of communication and knowledge, have subsequently adopted modern tools, thus gaining the power of the digital platform (Prensky, 2001).

9 The survey was conducted on March 14 and 15, 2018 on the sample of 60 subjects of the second grade (17 years) of the natural-mathematical classes of the Fifth Belgrade High School. The sample of subjects was matched by age, gender and experience (education and school success). A quantitative random cluster sample method, a questionnaire with numerical multiple choice variables, and a Likert scale were applied. Counts and percentages were applied when processing the data. 


\section{Results of the study Media habits of adolescents}

\section{Adolescent media content}

- media content consumed by adolescents daily is popular music, which respondents either listen to using their headsets on a smartphone or watch music videos on Youtube - of the total sample of subjects listening to popular music $96 \%$ more than an hour a day, $3 \%$ less than an hour a day, $1 \%$ not listening;

- fiction series $68 \%$ of respondents watch more than an hour a day, in most of the Game of Thrones and Vikings TV series, $11 \%$ of respondents watch TV series up to an hour a day, $21 \%$ of subjects do not watch series ${ }^{10}$;

- A significant percentage of respondents regularly watch movies $-86 \%$ of subjects sample at least one movie a week, $12 \%$ watch at least one movie a day, $2 \%$ say they don't watch movies;

- Sports broadcasts daily, for more than an hour, are followed by $54 \%$ of the sample of subjects (out of the total number of respondents who monitor sports broadcasts, $82 \%$ are male), $16 \%$ of respondents monitor occasional sports broadcasts, $30 \%$ do not monitor sports broadcasts ${ }^{11}$;

- About $14 \%$ of the sample of subjects occasionally read daily newspapers, mostly male, intending to check the results of sporting events (respondents read daily newspapers exclusively online), while $86 \%$ of the subjects did not read newspapers at all;

10 Epic fiction is the dominant movie genre in adolescents, which can be explained by their developmental psychological and emotional characteristics (escape from reality into fiction, lack of objectivity in perception, adventurous attitude towards life, desire to conquer the unknown, moving the boundaries of knowledge, etc.).

11 Respondents follow the daily newspapers exclusively in electronic form, via the Internet, on their smartphone or computer, which we found out in the discussion after the survey. 
- respondents consume less of the other program than other media (3\% follow some religious program, 97\% do not follow\% at all) and tabloids (1\% read tabloids, $99 \%$ do not read tabloids), while $100 \%$ said they did not consume political weeklies;

- A negligible number of respondents read magazines (two male respondents read magazines on weapons, one respondent reads "Politikin Zabavnik").

\section{Media Perception Channels}

- The channel through which adolescents commonly perceive media content is the Internet ${ }^{12}$;

- Popular music, which has proven to be the dominant media content, is mostly adopted by adolescents via Youtube and selected playlists $-98 \%$, while $2 \%$ listen to radio;

- In an open-ended interview, after conducting an empirical survey, the respondents agreed that television and radio were not included, but were monitoring television content (films and series) as well as radio (music) via video streaming platforms.

\section{Social media used by adolescents}

- WhatsApp is a favorite social media sample of the subjects ( $100 \%$ of respondents said they use it daily);

- $79 \%$ of Instagram followers out of the total;

- A Facebook profile has $76 \%$ of the total number of respondents;

- Viber follows $32 \%$ of the sample of subjects.

To the open-interview question in the last structural section of the questionnaire - Why do communication youth choose WhatsApp

12 In the discussion after the survey, through open-ended interviews, we learned that respondents use the Internet on a daily basis through their smartphones, to a lesser extent, the computers they use when they are at home. 
up rather than Viber?, a sample of subjects provided the following answers ${ }^{13}$ :

- "WhatsApp has a better interface"/ "WhatsApp has a nicer design"/ "Has better aesthetics"/"Has a nicer color"/ "It works more full while Viber is simpler, has less color"/"WhatsApp has nicer emoticons.")

- "I will not use the platform used by my parents."

- "Because my company uses WhatsApp."

- "WhatsApp can form a larger group than Viber."

- "WhatsApp takes up less memory."

- "Pictures sent from WhatsApp are better quality."

- "WhatsApp is easier to use - there are no stickers or unnecessary items, only messages and pictures are sent."

- "It's newer than Viber."

- "It's faster and more efficient."

- "It's modern."

- "Viber is more childish, designed for children and the elderly, and WhatsApp is suitable for young people - it's more fun, more dynamic and has a wider range of emoticons." ${ }^{14}$

\section{Analysis of results and conclusions of research Media habits of adolescents}

Given the relatively small sample of respondents (60 subjects of one high school), we will take a certain distance in the interpretation of the results. We hypothesize that a longitudinal study would provide useful valid results for determining the impact of cultural change on the adolescent-media relationship.

Research results show that a sample of subjects uses the media daily. The media contents that are most perceived by high school

13 The question is derived from the conclusion of the researcher (teacher) during many years of practice with students - adolescents most often communicate via WhatsApp.

14 The view highlights the most repetitive answers. 
students are (sorted by the order of perception of the sample of respondents): popular music, movies, series, and sports. Reality programs and tabloids consume a negligible percentage of the sample of subjects as well as magazines. Respondents do not consume political weeklies. The results of the research indicate that the habit of monitoring print media has not been established in young people.

Gender differentiation in responses was generally negligible, but it should be noted that male adolescents showed greater interest in sports broadcasts and daily newspapers on portals.

The dominant channel through which adolescents perceive media content is the Internet. Respondents perceive media content through "video streaming" platforms, primarily through Youtube, which has proven to be the most popular Internet service for video publishing and monitoring among adolescents. The cause of this phenomenon is to be found in the fact that it enabled the monitoring of media content using a smartphone, which qualified a sample of subjects in the discussion after surveying "the only subject without which they could not imagine their own lives".

The discussion following the empirical research provided us with a valuable conclusion: adolescents do not think about the types of media, but about media content. A significant portion of the sample of subjects watch multiple screens simultaneously mostly monitoring content on a smartphone and tablet, or on a smartphone and computer, confirming to a significant extent the presence of "media multitasking"15. Anxiety has been a general feature of existence in Western civilization since the beginning of the 21 st century.

15 The term "media multitasking" means viewing multiple screens at a time. The term comes from the English terminology dictionary for business (multitask - performing multiple tasks at the same time), from which, in addition to the term "media", it has been syntagmatically expanded to include everyday speech as well as the terminology of science (psychology, sociology, etc.). https://www.globifylanguages. com/business-english-vocabulary-multitask/. (Accessed: February 12, 2019). 
We would like to point to another observation arising from the results of this research: the choice of a communication channel in adolescents in the early 21st century is an expression of rebellion. What used to be jargon, rock roll, punk, a new subculture is today a communication platform. With the emergence of the first social communities, the social stratification of languages was also established. At the beginning of the 21st century, there was a stratification of communication channels by social groups - technological advances provided adolescents with an opportunity not to use the same communication channel as their parents, teachers, and other adult members of the community.

Listening to music through radios, turntables, cassette players, and 20th-century CD players have been replaced by audio perception via Youtube and selected playlists. This data points to the fact that adolescents in the early 21st century want to control and focus media content towards themselves, which is generally a feature of narcissistic culture from the beginning of the 21st century.

Traditional media programming strategies have been overcome - adolescents show a need for media content that is accessible, personalized, and emotionally engaging. Self-selected media stimuli irritate the field of predictable emotional responses, away from deeper reflection, so the possibility of intrapersonal communication is lost before it is even initiated. Leaving aside cognitive, expressive, and accumulative function, adolescents' language on social media has been reduced to the exchange of short, simplified notices, reduced communication. We expect that the changed way of communication, use of language, and perception of content from mediated reality will most affect literature as an art whose expressive tool is a language that implies an aesthetic component that "gives something more and something deeper", Kaiser (Kaiser, 1973).

In peer communication, adolescents use WhatsApp because it involves resources that meet their needs and, in turn, helps them maintain distance from adults. The semiotic system on WhatsApp is slightly different from the semiotic system on Viber - it is more picturesque, multicolored, and responds to adolescents' need to store more and more documents. The results indicate that young 
people have a strong connection to the media, the contents of which they select, share, and store in their phones.

\section{Conclusion}

The cultural identity of adolescents encompasses all the symbols and meanings that determine the belonging of that social group to the wider community, and that distinguish them, or make them similar, from other groups in that community. The attitude of adolescents towards the media, which occupy a very important place in their daily lives, can be seen as a reflection of the collective consciousness of a social group towards an important aspect of their self-actualization.

At the beginning of the 21st century, adolescents interact closely with the media daily, which determines the key points of their cultural identity. Theoretical consideration and analysis of the results of the empirical research helped us to determine which media content young people use the most today and in what way, as well as to identify social media that members of that social group use in interpersonal communication within and outside their group. We view these conclusions as important points for determining the cultural identity of adolescents in the digital age.

Adolescents in Serbia today are acquainted with multimedia content from their earliest childhood. Because of this, their perception of reality is significantly different from their parents' perception of reality. With an active daily attitude towards the media, adolescents today encourage the global mediation of society.

Media portray adolescents as conformist-oriented, facing superficial entertainment and modern information technologies. The controversy about the harmful impact of the media on young people most often stems from the growing number of examples of unacceptable behavior of adolescents, that is, to link adolescents' media habits with their risky behavior. Focusing on the negative effects of media on adolescents neglects the emotional engagement that adolescents establish with the media. Instead of the superior 
attitude coming from the world of adults (establishment, school, parents), as much well-conceived research on the correlation of adolescents and media content should be conducted, the results of which will provide insight into the world of adolescents, as well as adequate tools for developing their media literacy and critical thinking.

Epochs are changing, new technological products are replacing outdated ones, communication channels are evolving. The transition in digital culture has brought about changes in communication models. The results of the conducted research show that adolescents in Serbia at the beginning of the 21st century need media content that is personalized and emotionally engaged. The dominant channel through which adolescents perceive media content is the Internet - video streaming platforms, primarily Youtube. The results of the research show that adolescents need media content that is accessible, personalized, and emotionally engaged. Narcissism, as a developmental feature of adolescence, is in line with the principles of the conformist society of the new millennium.

In the mediacentric world, technologies are both social and cultural tools. With their help, today's adolescents present themselves and establish communication rituals. The new epoch requires the ability to critically perceive powerful images of multimedia culture, to understand their meaning, to grasp clearly text and subtexts, as well as to develop a skill in communicating and producing media messages.

Determining the cultural identity of adolescents in the present is important for insight into the determinants of the cultural identity of society in the future.

\section{References}

Anderson, J. (1983). Television literacy and the critical viewer. In J. Bryant and D. R. Anderson (Eds.) "Children's understanding of television: Research on attention and comprehension". New York: Academic Press. 
Avramović, Z. (2006). Kultura. Beograd: Zavod za udžbenike i nastavna sredstva.

Bodrijar, Ž. (1991). Simulakrum i simulacija. Novi Sad: Svetovi.

Bryant, J. \& Oliver, M. B. (2009). Media Effects Advances in theory and research. New York Routledge.

Buckingham, D. (1993). 'Going Critical: The Limits of Media Literacy', Australian Journal of Education, vol 27, no 2, p. 142-152.

Buckingham, D. (2003). Media Education: Literacy, Learning and Contemporary Culture, Cambridge: Polity Press, UK.

Carlsson, U., Tayie, S., Jacqinot-Delaunay, G. and Tornero, J. M. P. (2008). Empowerment Through Media Education, Goteborg: International Clearinghouse on Children, Youth and Media.

Gunter, B. (2008). 'Media violence. Is there a case for causality?' American Behavioral Scientist, 51 (8), p. 1061-1122.

Halloran, J. D. and Jones, M. (1992). 'The inoculation approach'. In M. Alvarado and O. Boyd-Barrett (Eds.), Media education: An introduction. London: British Film Institute, pp. 10-13.

Hobbs, R. (1998). 'The Seven Great Debates in the Media Literacy Movement', Journal of Communication, Winter, Washington: International Communication Association, pp. 11-48.

Jung, K. G. (1987). Čovjek i njegovi simboli, Zagreb: Mladost.

Kajzer, V. (1973). Jezičko umetničko delo, Beograd: Srpska knjizevna zadruga.

Kecman, V. (2017). 'Portret homo aestheticus-a u mladosti - godina 2016.' Homo aestheticus, UDK 111.852 (082.1), Beograd: Esteticko drustvo Srbije, pp. 391-403.

Lesli, V. (1970). Nauka o kulturi, Studija o čoveku i civilizaciji. Beograd: Kultura.

Nettlefold, J. \& Williams, K. (2018). Insight Five: A snapshot of Media Literacy in Australian Schools. Institute for the Study of Social Change, University of Tasmania. Available at: http://www.utas.edu.au/ data/assets/pdf_file/0005/1144409/Insight-Five-Media-Literacy. pdf. (Accessed: 12 February 2019).

Pavlović-Babić. D., Krnjević, Z, Pešić-Matijević, J, Gošović, R. (2001). 'Struktura sposobnosti i veština kritičkog mišljenja', Psihologija, 1-2, Beograd: Filozofski fakultet, pp. 195-208.

Prensky, M. (2001). Digital Natives, Digital Immigrant, On the Horizon, MCB University Press, Vol. 9 No. 5. Available at: http://www.marcprensky.com/writing/Prensky. (Accessed: 12 August 2019). 
Ruddock, A. (2013). Youth and Media, SAGE Publication of London, Thousand Oaks, New Delhi, and Singapore.

Sundar, S. (2009). Media effects 2.0 social and psychological effects communication technologies. U. R. Nabi and M. B. Oliver (book organizers). The Sage Handbook of Media Processes and Effects. Thousand Oaks, CA: Sage, pp. 545-560.

Thoman, E. \& Jolls, T. (2003). Literacy for the 21st Century - An Overview \& Orientation Guide To Media Literacy Education, Malibu, CA: Center for Media Literacy (CML).

Vranješević, L. (2004). 'Adolescencija, porodica i nasilje - nekad i sad'. Traganje za smislom: izazovi i rizici adolescencije, Beograd: IP 'Žarko Albulj', pp. 167-171.

Ćurčić, V. (2004). 'Traženje smisla u novoj (adolescentnoj) realnosti'. Traganje za smislom: izazovi i rizici adolescencije, Beograd: IP 'Žarko Albulj, pp. 11-20.

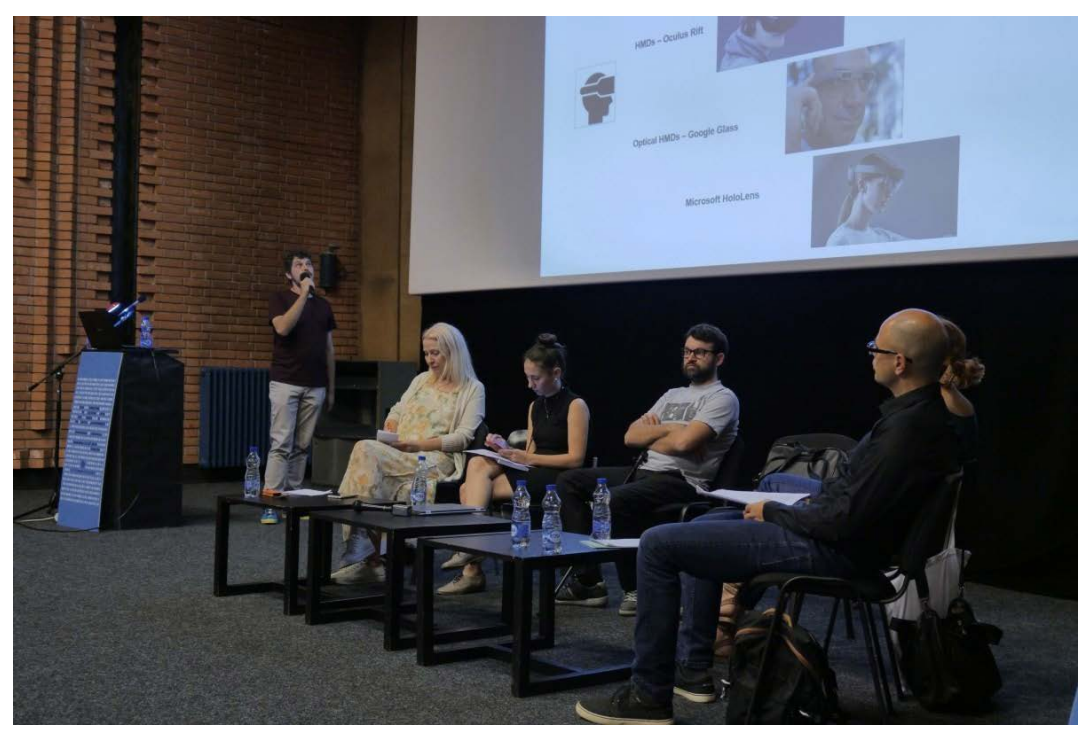

Znanje i obrazovanje u digitalnom okruženju, Nedeljko Kovačić, Dejana Prnjat, Tatjana Nikolić, Ivan Velisavljević, Simona Ješelnik i Miha Grum (FDU, 13. sept. 2019.) 
Виолейа Кеиман

Висока школа за комуникације, Београд

\section{КУЛТУРНИ ИДЕНТИТЕТ АДОЛЕСЦЕНАТА У СРБИЈИ У ДИГИТАЛНОМ ОКРУХЕЫУ}

Циљ рада је разматрање утицаја друштвеног дигиталног контекста на културни идентитет младих, као и указивање на правац даљег развоја идентификованих колективних трансформација у друштву. Резултати теоријског разматрања и емпиријског истраживања указују на значајан утицај глобалне нарцистичке културе на културни идентитет адолесцената, њихову снажну интеракцију са дигиталним медијима, интенцију ка персонализацији медија, присуство утврђених и шире прихваћених медијских навика, као и перцецију медијских садржаја путем раније усвојених канала перцепције. У емпиријском истраживању спроведеном 2018. године на узорку састављеном од ученика Пете београдске гимназије, примењени су метода квантитативног случајног узорка кластера, упитник са више избора и Ликертова скала. Закључци указују да су традиционалне стратегије медијског програмирања превазиђене - адолесценти показују потребу за медијским садржајем који је увек доступан, персонализован и емоционално ангажован. Резултати истраживања показују да адолесценти свакодневно користе медије, да је доминантан канал перцепције медијских садржаја Интернет, платформа за video streaming Youtube, који се показао као најпопуларнији за објављивање и дељење медијских садржаја. Адолесценти у дигиталној интерперсоналној комуникацији углавном бирају апликацију WhatsApp, јер технолошки одговара на њихове потребе, истовремено им омогућавајући да одрже дистанцу са одраслима, који исту апликацију користе у знатно мањој мери.

Кључне речи: културни идентитет, адолесценти, дигитални медији, медијски садржаји, медијске навике 